\title{
Identification of Specific Plasma Proteins Determining the Agarose Gel Electrophoresis by the Immunosubtraction Technique
}

\author{
By G. Merlini \\ Istituto di Patologia Medica 1, Università di Pavia, Italy \\ F. Pavesi \\ Laboratorio Analisi Chimico Cliniche, Policlinico S. Matteo, Pavia, Italy
}

\section{A. Carini, Irene Zorzoli,}

Istituto di Patologia Medica I, Università di Pavia, Italy

O. Valentini

Istituto di Genetica Biochimica ed Evoluzionistica, CNR, Pavia, Italy, and

\author{
F. Aguzzi \\ Laboratorio Analisi Chimico Cliniche e Microbiologiche, Ospedale di Broni e Stradella, Pavia, Italy
}

(Received April 25/September 13, 1983)

Summary: The immunosubtraction technique was used to identify the proteins in electrophoretically separated plasma. The technique consists of forcing the plasma through a layer of monospecific antibody purified by electrophoresis; the specific protein is thereby precipated and is consequently absent from the subsequent electrophoretogram. This technique was successfully applied to the following proteins (in order of distance from the anode): prealbumin, albumin, $\alpha$-lipoproteins, $\alpha_{1}$-antitrypsin, Gc-globulins, $\alpha_{2}$-macroglobulin, haptoglobin, fibronectin, transferrin, $\beta$-lipoproteins, $\mathrm{C} 3$, fibrinogen. The method may be applied to the study of protein polymorphism.

Identifizierung spezifischer Plasmaproteine mit Agarosegel-Elektrophorese durch Immunsubstraktions-Technik

Züsammenfassung: Die Immunsubtraktions-Technik wựde für die Identifizierung der Proteine in elektrophoretisch getrenntem Plasma angewandt. Die Technik beruht auf der Wanderung des Plasmas durch eine Schicht von elektrophoretisch gereinigtem monospezifischen Antikörper; das spezifische Protein wird dadurch präzipitiert und ist daher im folgenden Elektropherogramm nicht mehr vorhanden. Diese Technik wurde für folgende Proteine (in Reihenfolge der Entfernung von der Anode) erfolgreich angewandt: Präalbumin, Albumin, $\alpha$-Lipoproteine, $\alpha_{1}$-Antitrypsin, $G=-G l o b u l i n e, \alpha_{-2}$-Macroglobulin, Haptoglobin, Fibronectin, Transferrin, $\beta$-Lipoproteine, $C 3$, Fibrinogen. Die Methode kann zum Studium von Protein-Polymorphismen angewandt werden.

\section{Introduction}

Agarose gel electrophoresis of plasma proteins has come into more and more frequent use in clinical laboratoriès, especially in the last decade. The technique allows the analysis, by simple visual inspection, of various proteins which altogether make up
90-95 per cent of the plasma protein mass: prealbumin, albumin, $\alpha$-lipoproteins, $\alpha_{1}$-antitrypsin, Gcglobulin, $\alpha_{2}$-macroglobulin, haptoglobin, transferrin, $\beta$-lipoproteins, $C 3$, fibrinogen, $\operatorname{IgA}$ and $\operatorname{IgG}(1,2$, 3). Clinically useful interpretation involves the visual semiquantitative estimation of each specific protein separated on the electrophoretogram. 
The specific proteins producing the agarose gel electrophoretogram have been known for years, but no direct experimental evidence has yet been reported. A useful tool for the analysis of the electrophoretic bands is "immunosubtraction". i. e. immunoprecipitation of individual proteins with monospecific antisera prior to the electrophoretic migration of the serum $(4,5)$. It allows removal of single proteins without otherwise altering the electrophoretic pattern. The antiserum is often available as total serum or as a gamma globulin fraction with contaminants. Therefore it is necessary to first remove all its nonimmunoglobulin components that otherwise would migrate together with the corresponding fractions of the sample serum. This goal is accomplished by a preliminary electrophoresis of the antiserum which separates the gamma zone from all other fractions.

\section{Materials and Methods}

The electrophoretograms were performed on $10 \times 20 \mathrm{~cm}$ plates of $1 \mathrm{~mm}$ thick Agarose ME (Marine Colloids, Miles Lab. Ltd., Stoke Poges, GB) $7.5 \mathrm{~g} / \mathrm{l}$ in diethyl barbiturate buffer $75 \mathrm{mmol} / \mathrm{l}$, $\mathrm{pH} 8.6$, containing $2 \mathrm{mmol} / \mathrm{l}$ of Ca lactate. A Multiphor apparatus (LKB, Bromma, Sweden) was used. Monospecific antisera were purchased from Behringwerke (Marburg, D), Dako (Copenhagen, DK) and Meloy (Springfield, VA, USA). Fixing solution: picric acid $15 \mathrm{~g}$ added to 1 liter $\mathrm{H}_{2} \mathrm{O}$, the solution was filtered and $200 \mathrm{ml}$ acetic acid were added. Staining solution: Coomassie Brillant Blue R-250 $2 \mathrm{~g} / \mathrm{l}$ in destaining solution (methanol, acetic acid, $\mathrm{H}_{2} \mathrm{O}, 9+2+9$, by volume).

The immunosubtraction technique consists of two steps:

1) electrophoretic purification of the gamma fraction of the antiserum,

2) electrophoresis of the sample through the purified antibodies.

A total amount of $100 \mu \mathrm{g}$ of monospecific antibody $(10-20 \mu \mathrm{l}$ de pending on the gamma fraction concentration of the antisera) was applied with a microsyringe using a thin plastic sheet with wells $(1 \times 10 \mathrm{~mm})$ cut into it and positioned at a distance of two centimeters from the border of the plate. The antisera were applied in alternate wells, leaving the adjacent wells free for the control, i.e. non-immunosubtracted, sera. Once absorbed, the antisera were subjected to electrophoresis at $20 \mathrm{~V} / \mathrm{cm}$ for $45 \mathrm{~min}$, the anode being connected by means of an agarose gel bridge with the border of the plate near the deposition sites. After this preliminary electrophoresis a strip of agarose gel, $1.5 \mathrm{~cm}$ wide, was removed from the deposition side of the plate (because it is contaminated with the non-gamma fractions of the antisera) and replaced with a new strip of the same gel. Three microliters of the sample diluted $1: 2$ or $1: 3$ with saline containing bromophenol-blue were placed in the wells previously filled with the antisera, and in the adjacent wells which had been left free for comparative analysis; immunosubtracted and non-immunosubtracted samples therefore migrated in parallel. The second electrophoretic run was carried out with inverted polarity (the side where the samples had been applied was connected with the cathode). Then the samples were electrophoresed at $10 \mathrm{~V} / \mathrm{cm}$ for the first $15 \mathrm{~min}$ and at $20 \mathrm{~V} / \mathrm{cm}$ for the following 30-40 min (final albumin migration: $7.5 \mathrm{~cm}$ ). The current intensity was kept initially lower in order to facilitate the antigen-antibody reaction. After migration thé plate was fixed for about $20 \mathrm{~min}$, then blotted, dried and stained.

\section{Results}

Results are illustrated by the electrophoretograms of figures 1 and 2 . Wells $1,3,7,9$ and 11 of figure 1 contain reference sera. In well 2 immunosubtraction with anti-prealbumin antiserum caused the disappearance of the faint band anodal; to the albumin. In well 4 anti- $\alpha$-lipoproteins antiserum has caused fading of the broad band between albumin and $\alpha_{1}$-antitrypsin. In the adjacent well anti- $\alpha_{1}$-antitrypsin antiserum has caused the disappearance of the $\alpha_{1-}$ band. In well 6 immunosubtraction with anti-Gcglobulin antiserum has caused the disappearance of the two faint bands immediately anodic to $\alpha_{2}$-band.

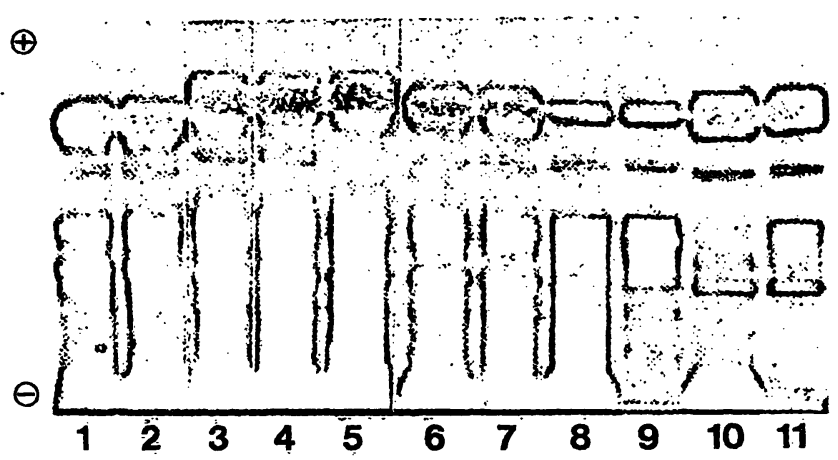

Fig. 1. Immunosubtraction on agarose gel. Samples $(3 \mu$ diluted $1: 2): 1-7$, normal sera; 8 and 9 , sera from a child with acute flogosis (haptoglobin increased), 10 and 11 , sera from a newborn ( $\alpha_{2}$-macroglobulin increased). Antisera $(10-20 \mu \mathrm{l}): 2$, anti-prealbum= in; 4 , anti- $\alpha$-lipoproteins; 5 , anti- $\alpha_{1}$-antitrypsin; 6 , antiGc-globulin; 8, anti-haptoglobin; 10 , anti- $\alpha_{2}-$ macroglobulin.

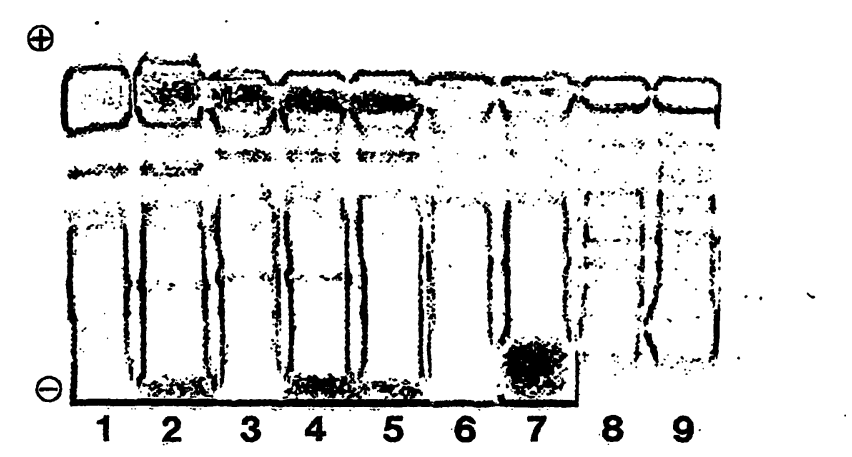

Fig. 2. Immunosubtraction on agarose gel.

Sample $(3 \mu$ diluted $1: 2): 1$ and 2 , sera from a patient treated with penicillin; 3,4 and 5 , normal sera; 6 and 7 , sera from a patient with increased $\beta$-lipoproteins; 8 and 9 . normal plasma diluted $1: 3$, the additional band conipared in $\alpha_{1}-\alpha_{2}$-zone in sample 9 is probably due to immunocomplexes.

Antisera $(10-20 \mu l): 2$, anti-fibronectin; 4 , anti-C3; 5 , anti-transferrin; 7 , anti- $\beta$-lipoproteins; 9 , anti-fibrinogen. 
The reference serum in well 9 is from a child with acute flogosis and documented increase of haptoglobin $(3.8 \mathrm{~g} / \mathrm{l}$, reference range $0.27-1.40)$ : the anti-haptoglobin antiserum in well 8 caused the disappearance of the broad intense band determining the cathodic part of the $\alpha_{2}$-zone, leaving a narrow intense band forming the anodic part of the $\alpha_{2}$-zone. The wavy band forming the background in $\alpha_{2}$-zone is due to lipoproteins. The reference serum in well 11 is from a newborn with an increased level of $\alpha_{2}$-macroglobulin $(4.9 \mathrm{~g} / 1$, reference range $1.7-4.2)$. The anti- $\alpha_{2}$-macroglobulin antiserum in well 10 caused almost complete disappearance of the anodic part of the $\alpha_{2}$-band.

In figure 2 reference sera are in wells 1,3 and 6 . In well 2 the anti-fibronectin antiserum caused the disappearance of the thin band between $\alpha_{2}$-zone and $\beta_{1}$-band. In well 4 , anti-C3 antiserum has caused the "subtraction" of the $\beta_{2}$-band, while in the adjacent well anti-transferrin antiserum has caused the disappearance of $\beta_{1}$-band, leaving as background a wavy band formed by $\beta$-lipoproteins. This wavy band disappears with anti- $\beta$-lipoproteins antiserum in well 7 . In well 8 there is reference plasma: the band between the $\beta_{2}$ - and $\gamma$-zones disappears on treatment with anti-fibrinogen antiserum (see well 9).

Figure 3 shows an application of the immunosubtraction technique. A serum presented two bands in the $\alpha_{1}$-zone, the most likely explanations being heterozygosis of $\alpha_{1}$-antitrypsin or the presence of $\alpha_{1}-\mathrm{fe}$ toprotein. Immunosubtraction with anti- $\alpha_{1}$-antitrypsin antiserum led to the disappearance of both bands, showing the presence of $\alpha_{1}$-antitrypsin heterozygosis.

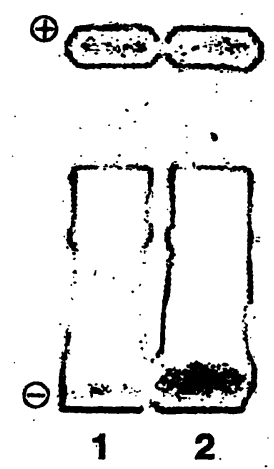

Fig. 3: Immunosubtraction on agarose gel: Serum containing doubled $\alpha_{1}$-band $(3 \mu l$ diluted $1: 2)$ immunosubtracted with anti- $\alpha_{1}$-antitrypsin $(20 \mu \mathrm{l})$.
Immunosubtraction of albumin gave complete disappearance of the specific band when tested serum was highly diluted $(1: 20,1: 50)$. Other plasma proteins: orosomucoid, $\alpha_{1}$-antichymotrypsin, inter- $\alpha$-trypsininhibitor, $\alpha_{2} \mathrm{HS}$-glycoprotein, hemopexin, caeruloplasmin, $\mathrm{C} 4$ and $\mathrm{C} 5$ were also tested by immunosubtraction; no modification of the electrophoretic pattern was observed.

\section{Discussion}

The immunoprecipitation of individual plasma proteins with monospecific antisera prior to electrophoresis (immunosubtraction) makes it possible to determine the true identity of the proteins in the electrophoretic pattern. This cannot be achieved by immunofixation $(6,7)$ or by immunoelectrophoresis, which also detect proteins present in very low concentrations, or poorly stained proteins, which therefore do not make a significant contribution to the production of the electrophoretic pattern. The intensity of the individual bands may in fact depend not exclusively on their concentration, but also on their staining properties (e.g. orosomucoid is not stainable with Coomassie Brillant Blue R-250) and on the spread of their electrophoretic distribution (e.g. $\alpha$ and $\beta$-lipoproteins show an electrophoretic heterogeneity). The attenuation or disappearance of an electrophoretic band after immunosubtraction with a monospecific antiserum allows the immediate individuation of the protein responsible for that band.

The immunosubtraction technique achieves two goals:

1) purification of the gamma fraction of the antiserum,

2) selective subtraction, i.e. identification, of a specific protein.

These two goals may be achieved in other ways. The antiserum could be purified by chromatography (ion exchange or affinity) but this approach requires a much greater volume of antiserum (immunosubtraction requires $10-20 \mu \mathrm{l}$ ), a longer operating time, specific instrumentation and technical skill. The selective removal of a protein has been accomplished by affinity chromatography (8) in combination with immunoprecipitation and deletion (5). The affinity chromatography requires preparation of the immunoadsorbent, greater reagent and sample volumes and specific technical support. The immunoadsorption in liquid phase requires previous purification of the antibody and, again, more reagents, even if performed on a "micro scale". 
The results showed that several bands (prealbumin, albumin, $\alpha_{1}, \beta_{1}, \beta_{2}$ and fibrinogen) are each essentially formed by a single protein, while within the same band, immunofixation reveals the presence of various proteins. This has a great practical importance with respect to the molecular interpretation of the electrophoretogram for diagnostic purposes. The faint band which often appears on the electrophoretograms in the $\alpha_{2}-\beta_{1}$ interzone was shown to be due to fibronectin.

The bands which disappear after immunosubtrac=tion with monospecific antisera are from the anode: prealbumin, albumin, $\alpha$-lipoproteins, $\alpha_{1}$-antitrypsin, Gc-globulin, $\alpha_{2}$-macroglobulin, haptoglobin, fibronectin, transferrin, $\beta$-lipoproteins, $\mathrm{C} 3$ and fibrinogen. Other plasma proteins present in low concen-

\section{References}

1. Jeppsson, J.-O., Laurell, C.-B. \& Franzén, B. (1979) Clin. Chem. 25, 629-638.

2. Johansson, B. (1972) Scand. J. Clin. Lab. Invest. 29, Suppl. $124,7-19$.

3. Laurell, C.-B. (1972) Scand. J. Clin. Lab. Invest. 29, Suppl. 124, 71-82.

4. Aguzzi, F. \& Poggi, N. (1977) Boll. Ist. Sierot. Milanese 56, 3-9.

5. Allen, R. C., Arnaud, P. \& Spicer, S. S. (1981) in Electrophoresis '81 (Allen, R. C. \& Arnaud, P., eds) pp. 167-179, Walter de Gruyter, Berlin-New York. tration do not seem to affect the electrophoretic pattern.

The method is not applicable to the gamma region where the immunoprecipitation occurs. In practice, however, this is not important, because the alterations of the gamma zone are generally due to immunoglobulins and can be studied through the various immunoelectrophoretic techniques.

The immunosubtraction technique also may be useful as an adjunct to methods for the differentiation of protein heterozygosis ( $\alpha_{1}$-anti-trypsin or transferrin), and of monocional components (usually light chains, which move out of the gamma zone) from other similarly migrating protein bands. The method may also be used for the study of proteins on agarose gel electrophoretogram of other biological fluids.

6. Alper, C. A. \& Johnson, A. M. (1969) Vox. Sang. 17, 445$4 \dot{5} 2$.

7. Cawley, L. P., Minard, B. J., Tourtellotte, W. W., Ma, B. I. \& Chelle, C. (1976) Clin. Chem. 22, 1262-1268.

8. Arnaud, P., Galbraith, R. M., Chapuis-Cellièr, C., Galbraith, G. M. P. \& Fudenberg, H. H. (1978) in Protides of the Biological Fluids, Proç. 26th Colloquium (Peeters, H. ed) pp. 649652, Pergamon Press, New York.

Giampaolo Merlini M. D.

Istituto di Patologia Medica I

Policlinico S. Matteo

I-27100 Pavia 


\section{Sie können sich \\ Ihre Laborarbeit \\ ganz schön erleichtern...}

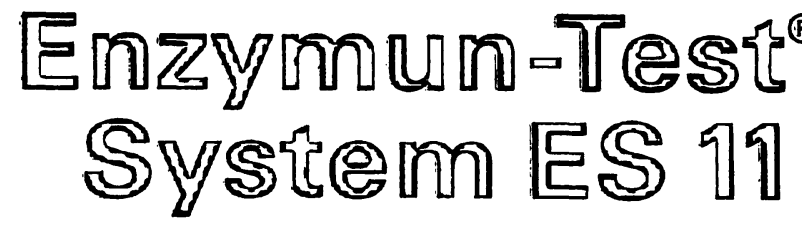
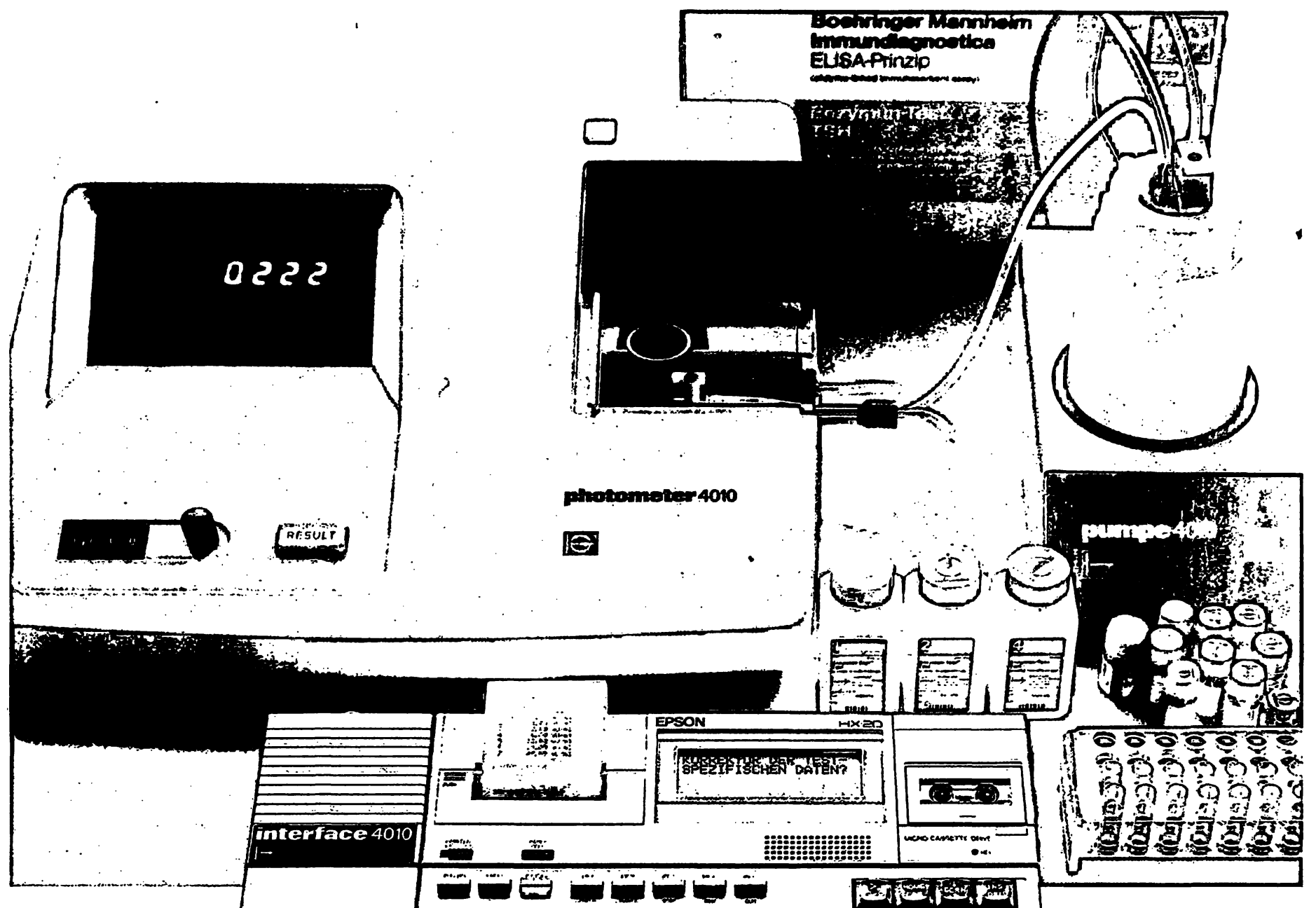

- Photometer und Rechner passen sich ihrer individuellen Arbeitsgeschwindigkeit an Standardkurven werden tis 100 a

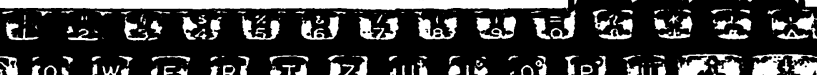

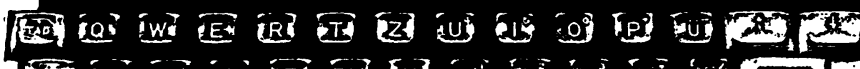

speichert und damit permanent verfügbar

Bis 15 verschiedene Methoden können gespeichert werden mittels einer komplexen mathematischen Funktion ("Splinefunktion") optimal berechnet und als Kurve dargestellt Mittelwerte von Einzelextinktionen werden berechnet Ausreißer werden angezeigt Daten sind auf Kassetten abge-

werden vollständig ausgedruckt $\bullet$ Ein Dialog des Benutzers mit dem Rechner ist über den eingebauten Bildschirm möglich - Das ES 11 ist zukunftssicher da es auch für neue Methoden ohne Modifikation ausgelegt ist.

\section{Die vollautomatische Auswertung der Enzymun-Test-Diagnostica von Boehringer Mannheim}

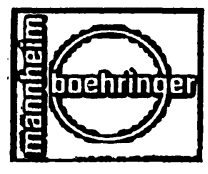

Boehringer Mannheim $\mathrm{GmbH}$, 6800 Mannheim 31 


\section{Walter de Gruyter Berlin-New York}

R. Hakenbeck, J.-V. Höltje, H. Labischinski (Editors)

E. M. Spencer (Editor)

F. Hucho

Y. A. Ovchinnikov (Editors)

J. A. Blair (Editor)

H. Wachter

H. Ch. Curtius

W. Pfleiderer

(Editors)

\section{The Target of Penicillin}

The Murein Sacculus of Bacterial Céll Walls Architecture and Growth

Proceedings - International FEMS Symposium Berlin (West), Germany, March 13-18, 1983 $1983.17 \mathrm{~cm} \times 24 \mathrm{~cm}$. XXVIII, 663 pages. Numerous illustrations. Hardcover. DM 180;-; approx. US \$82.00 ISWBN 3110097052

\section{Insulin-Like Growth Factors / Somatomedins}

Basic Chemistry · Biology · Chemical Importance

Proceedings of a Symposium on Insulin-Like Growth Factors / Somatomedins, Nairobi, Kenya, November 13-15, 1982 1983. $17 \mathrm{~cm} \times 24 \mathrm{~cm}$. XIII, 664 pages. Numerous illustrations. Hardcover. DM 240,-; àpprox. US \$109.25 ISBN 311.0095629

\section{Toxins as Tools in Neurochemistry}

Proceedings of the Symposium Berlin (West), March 22-24, 1983

1983. $17 \mathrm{~cm}$ x $24 \mathrm{~cm}$. XIV, 368 pages. Numèrous illustrations. Hardcover. DM 180,-; approx. US \$82.00 ISBN 3110095939

\section{Chemistry and Biology of Pteridines}

Pteridines and Folic Acid Derivatives

Proceedings of the 7th International Symposium on Pteridines and Folic Acid Derivatives • Chemical, Biological and Clinical Aspects . St. Andrews, Scotland, September 21-24, 1982 $1983.17 \mathrm{~cm} \times 24 \mathrm{~cm}$. XXXIV, 1070 pages. Numerous illustrations. Hardcover. DM 280,-; approx. US \$127.50 ISBN 3110085607

\section{Biochemical and Clinical Aspects of Pteridines, Vol. 1}

Cancer $\cdot$ Immunology $\cdot$ Metabolic Diseases $1982.17 \mathrm{~cm} \times 24 \mathrm{~cm}$. XV, 37́3 pages. Hardcover. DM 150,-; approx. US:\$68.25 ISBN $311008984 \mathrm{X}$ 